
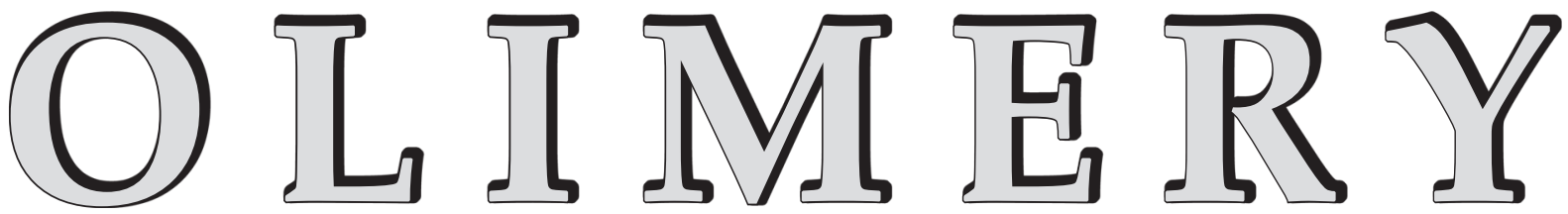

\title{
Characteristics of injection molded parts with the areas of weld lines
}

\author{
Elżbieta Bociąga $^{1), *)}$, Władysław Skoneczny ${ }^{1)}$
}

DOI: dx.doi.org/10.14314/polimery.2020.5.1

\begin{abstract}
The weld lines in injection molded parts arise as a result of the collision of two fronts of the flowing material, which fills the mold cavity and are sometimes unavoidable. They decrease the mechanical properties and surface state of the moldings, due to insufficient connection of the fronts of melted polymer streams. The paper discusses the reasons for the occurrence of weld lines in molded parts, which have been divided into ones related to the design of the injection molded part, properties of the injected material, injection mold construction and injection parameters. The design of the molded parts should ensure even, smooth flow of the material in the cavity, but in the case of parts with many injection points, holes, varied wall thickness, complicated and irregular structure the weld lines can not be avoided. The type of material processed significantly influences the strength of the weld line area. Too high viscosity of the material, fillers and large particles of the coloring agent highly oriented in the weld line area, are the factors lowering properties of the molded part. Considering the design of the injection mold, the most important aspects in forming proper parts with weld lines are correct venting of the mold, small differences in the material temperature in all cavity areas, correctly selected injection points, avoiding jet filling of the cavity. The quality of such parts can be improved by changing the injection conditions, mainly by increasing the mold and melt temperature, also increasing the holding pressure and the injection speed. The possibilities of preventing the weld lines creation or reducing the negative effects of their occurrence have been presented, e.g. by changing the design and location of gates in injection molds, changing processing conditions or using unconventional methods of injection molding, like cascade cavity filling, push-pull and multiple live-feed injection molding, vibration process. Further examinations in the range of cyclic heating/cooling of the injection mold are suggested as the most promising regarding the quality of parts in the area of weld line, their strength and surface state.
\end{abstract}

Keywords: injection molding, molded parts, weld lines, meld lines.

\section{Charakterystyka wyprasek wtryskowych z obszarami łączenia strumieni tworzywa}

Streszczenie: Obszary łączenia strumieni tworzywa w wypraskach wtryskowych powstają w wyniku zderzenia się ze sobą dwóch frontów przepływającego tworzywa, wypełniającego gniazdo formujące, i są niekiedy zjawiskiem nieuniknionym. Z powodu niedostatecznego połączenia ze sobą frontów stru-

1) University of Silesia in Katowice, Faculty of Sciences and Technology, Institute of Materials Engineering, Żytnia 12, 41-200 Sosnowiec, Poland.

*) Author for correspondence: elzbieta.bociaga@us.edu.pl 
mieni uplastycznionego tworzywa pogarszają się właściwości mechaniczne oraz stan powierzchni wyprasek. Omówiono przyczyny występowania obszarów łączenia strumieni tworzywa w wypraskach związane z: budową wypraski, właściwościami wtryskiwanego tworzywa, konstrukcją formy wtryskowej oraz warunkami wtryskiwania. Budowa wyprasek powinna zapewniać równomierny przepływ materiału w gnieździe formującym, jednak w wypadku wyprasek z wieloma punktami wtrysku, otworami, zróżnicowaną grubością ścianek, skomplikowanym kształtem nie można uniknąć powstawania linii łączenia strumieni tworzywa. Rodzaj przetwarzanego materiału ma istotny wpływ na wytrzymałość obszaru łączenia strumieni tworzywa. Zbyt duża lepkość tworzywa, obecność napełniaczy i dużych cząstek środka barwiącego silnie zorientowanych w obszarze linii łączenia są czynnikami pogarszającymi właściwości formowanych wyprasek. Do najważniejszych czynników, uwzględnianych podczas projektowania formy wtryskowej, decydujących o wytwarzaniu poprawnych wyprasek z liniami łączenia strumieni tworzywa zalicza się: prawidłowe odpowietrzanie formy, niewielkie różnice w temperaturze materiału we wszystkich obszarach gniazda formującego, odpowiednio dobrane punkty wtrysku oraz unikanie strumieniowego wypełniania gniazda. Jakość takich wyprasek można także poprawić w wyniku zmiany warunków wtryskiwania, głównie zwiększenia temperatury formy i tworzywa wtryskiwanego, a także zwiększenia ciśnienia docisku i prędkości wtrysku. Przedstawiono możliwości zapobiegania powstawaniu obszarów łączenia strumieni tworzywa lub ograniczania negatywnych skutków ich występowania, np. w wyniku zmiany budowy i usytuowania przewężek $\mathrm{w}$ formach wtryskowych, zmiany warunków przetwarzania lub zastosowania niekonwencjonalnych metod wtryskiwania, takich jak: wtryskiwanie kaskadowe, pulsacyjne liniowe i rozdzielcze lub wibracyjne. Dalsze badania w zakresie wtryskiwania z cyklicznym nagrzewaniem/ochładzaniem formy wtryskowej są sugerowane jako najbardziej obiecujące pod względem otrzymywania dobrych jakościowo wyprasek w obszarze łączenia strumieni tworzywa, o dużej wytrzymałości i dobrym stanie powierzchni.

Słowa kluczowe: wtryskiwanie, wypraski wtryskowe, obszary łączenia strumieni tworzywa.

The weld lines in injection molded parts arise as a result of the collision of two fronts of the flowing material, which fills the mold cavity and are sometimes unavoidable [1-4]. They degrade the mechanical properties and surface condition of the moldings, due to insufficient connection of the fronts of plastic streams. This is caused by, among other things, air bubbles between them, and the orientation of polymer macromolecules and filler.

The mechanism of the formation of visible traces on the surface of the moldings at the place where the two streams of material collide with each other has its base in the viscoelastic properties of the polymer and is dependent on the conditions of the injection molding process. The liquid material, when flowing through the cold channels of the injection mold, quickly solidifies at the wall of the cavity. The material on the stream front has a lower temperature than the material in the core. When two fronts of cooled material collide with each other, a V-shaped notch forms on the surface of the part [5-8]. The formation of this notch is also favored by the problem of air/gas evacuation from the place where the fronts of the plastic streams collide. One solution is to use a mold vacuum venting before injecting the material into the cavity, also beneficial due to shortening the time needed to fill it. The scheme of the formation of this surface defect is shown in Fig. 1. The resulting V-notch is not only a surface defect (increased surface roughness, change in colour, gloss), but also a place of stress concen-

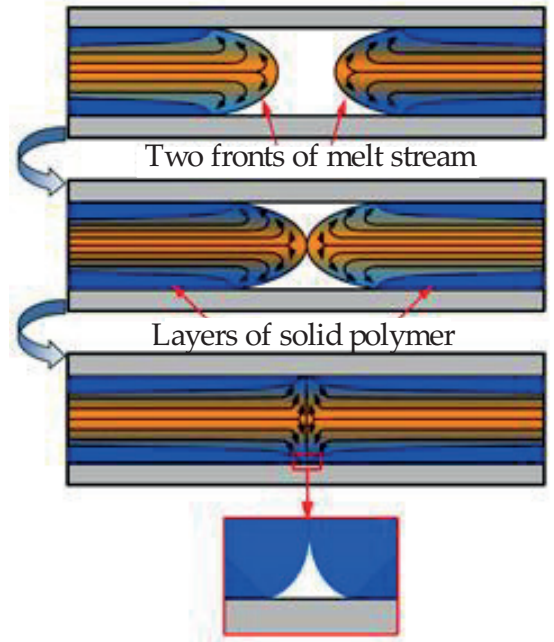

Fig. 1. The process of weld line forming (based on [5])

tration, which results in the weakening of the part, which is particularly important when it is stretched or bent.

Figure 2 shows the model structure of the area of joining of plastic streams, developed by Malloy [9]. In the core of the part there is a stronger bonding of streams, while in the surface layers unfavorable orientation of macromolecules, which is the effect of the fountain flow of streams in the mold channel, is the cause of the V-notch formation and weakening of the material in this zone.

Depending on the angle at which two streams of the material collide, one can distinguish the areas of the perpendicular (weld lines) and parallel (meld lines) connec- 


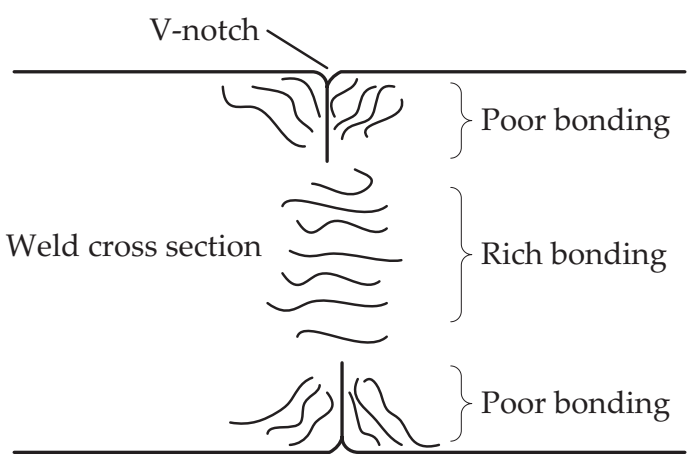

Fig. 2. Model depiction of the structure of the weld line area (based on [9])
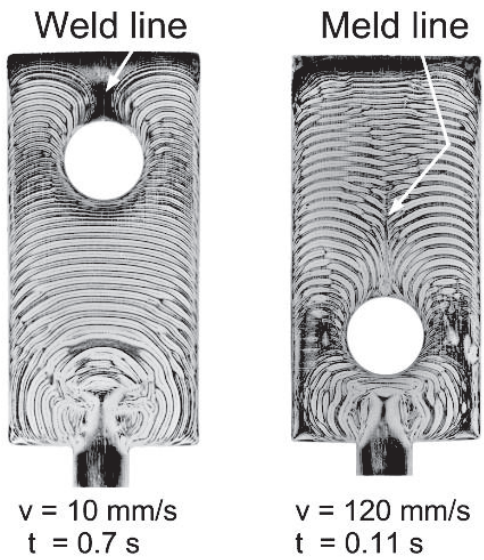

Fig. 4. Polyoxymethylene parts with: a) weld lines, b) meld lines obtained at different injection velocity $(v)$ and injection time (t) [11]

tion of them (Fig. 3). The classification criterion is the angle $(\theta)$ between the tangents to the flow fronts at their point of contact. It is assumed conventionally [10-12] that if $\theta<135^{\circ}$, then this is the area of perpendicular joining, and in the opposite case - parallel joining. Areas of parallel joining of plastic streams are characterized by higher strength and are less visible on the surface than perpendicular joining areas. This is due to the more favorable orientation of the macromolecules in the area in which there is a parallel flow of the streams of the material in relation to each other [12]. It has been shown that at the angle in the range from $120^{\circ}$ to $150^{\circ}$, depending on the type of material, the areas of joining streams are hardly visible or completely invisible [9].

Figure 4 illustrates the weld and meld lines formation in parts made of polyoxymethylene (POM), obtained from 16-cavity mold with different cavities allowing to form parts with holes placed near and far from the gate [11]. Parts were formed at the processing conditions, which were chosen so that the flow lines pattern on part surface was visible (too short injection time, low injection velocity). The occurrence of areas of joining plastic streams usually can be easily observed on the surface of moldings [13-15]. Some examples of moldings with such areas are shown in Fig. 5.

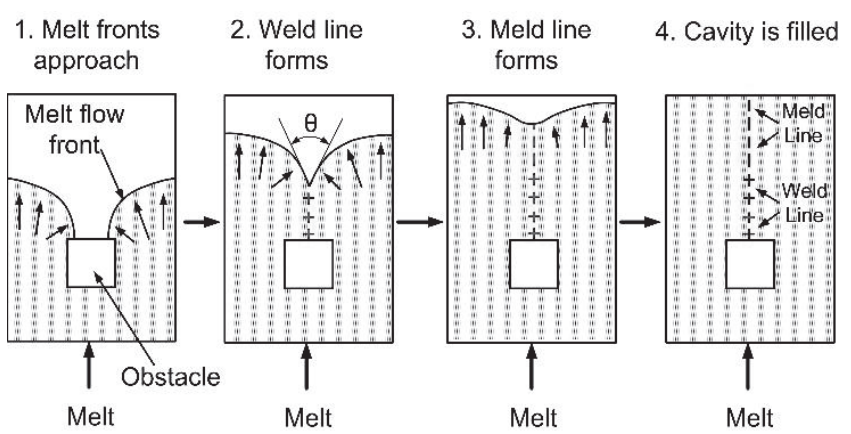

Fig. 3. Creation of weld and meld lines during filling of the cavity with the core forming the hole $[10,11]$
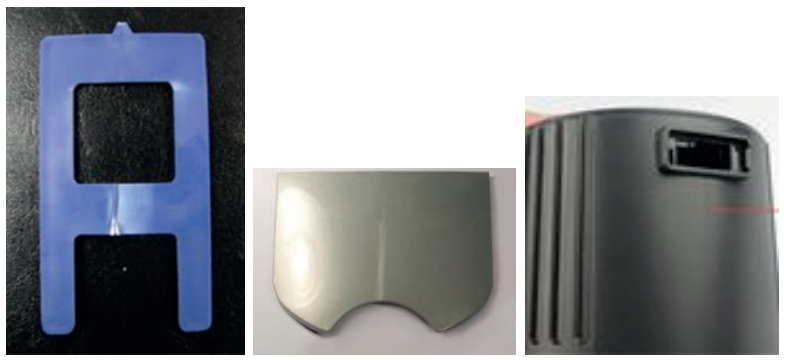

Fig. 5. Examples of injection molded parts with visible weld lines [13-15]

The reasons for the areas of weld lines occurring in parts can be divided into those related to [13]:

- construction of the molding (many injection points, holes, varied wall thickness, complicated and irregular structure causing a variable flow rate of the material in individual areas of the cavity),

- properties of the injected material (too high viscosity of the material, fillers, large particles of the colouring agent),

- construction of the injection mold (incorrect venting of the mold, different temperature of the material in the individual areas of the cavity, incorrectly selected injection points, jet filling of the cavity),

- injection conditions (too low injection speed, too low mold temperature and melt temperature, low holding pressure).

The areas of weld lines in injection molded parts are usually not the result of imperfections of the processed material, injection molding machine, mold or technological process and are difficult to eliminate, and result mainly from the construction of the molded part. Traces of weld areas are particularly visible on dark or transparent moldings, with smooth and high gloss polished surfaces, or on parts filled with glass fibres. The conditions conducive to the formation of such defects are also 
additives that give special metallic effects, e.g. pearlescent pigments or pigments with metal plates.

\section{CONSTRUCTION OF THE INJECTION MOLDED PART}

The way of flow of the liquid material in the cavity has a significant impact on the strength and appearance of the surface of the weld area. First of all, it is necessary to ensure that the flow fronts, after a collision, have the possibility of a further parallel flow facilitating their connection.

The position of the joining area of the material streams depends on the method of feeding the material to the cavity and the location of the gates. The gate must be positioned in such a place that it will provide a weld area in the part, in an unloaded place during use, or invisible to the user. With multi-point cavity feeding, some gates can be blocked to limit the number of streams of material, which is not always possible. Sometimes, however, it is even advisable to increase the number of injection points in order to shorten the flow path, and receive collision of melt fronts with a higher temperature and higher flow velocity, and, as a result, obtain greater strength of the joining areas (Fig. 6) [9].

The design of the molded parts should ensure even, smooth flow of the material in the cavity. The ribs, the projections in the moldings should be designed in the direction of flow of the material to facilitate proper cavity filling and venting. In the case of parts with holes, the weld lines can not be avoided. The material during cavity filling is divided into two streams flowing around the mandrel forming the hole behind which the bonding is formed. In this case, it is possible to design an additional overflow channel to facilitate venting of the joining area of the streams and their better connection (Fig. 7a) or a rib of greater thickness to reinforce this area (Fig. 7b) [16, 17].
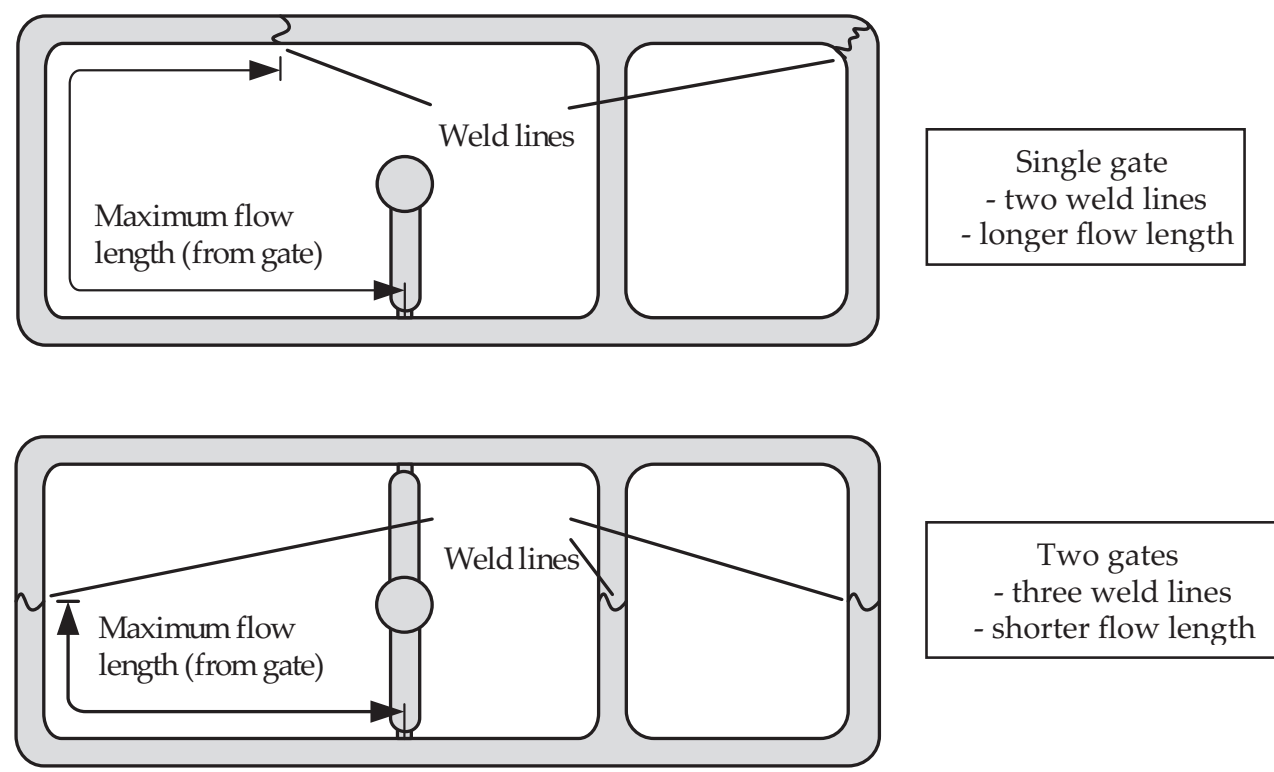

Fig. 6. Weld lines at different number of gates (based on [9])

a)

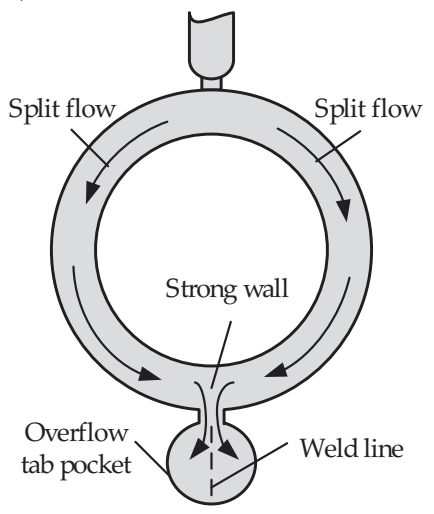

b)

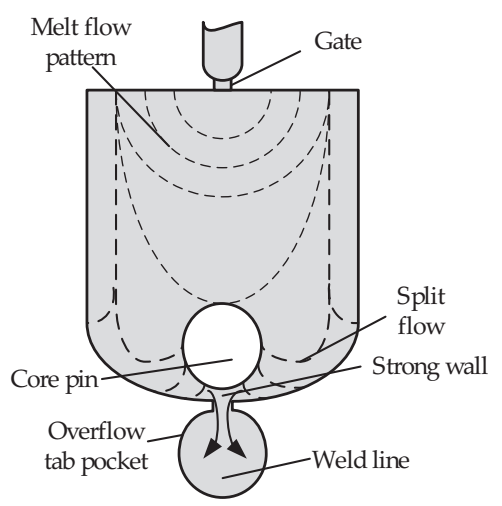

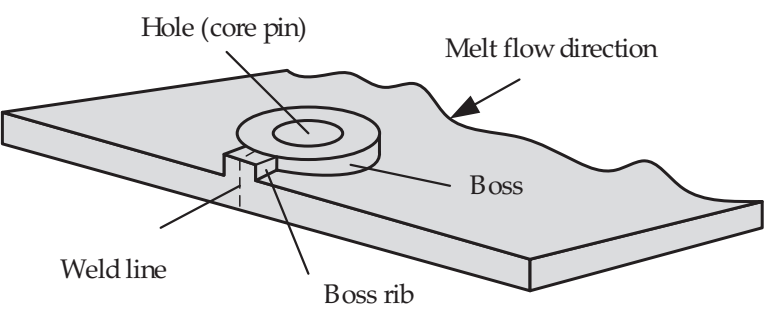

Fig. 7. Use of: a) an additional channel, b) a thick rib to improve the quality of the area of weld lines (based on [17]) 
a)

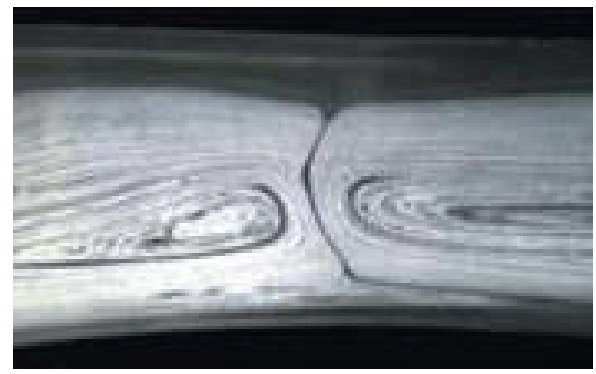

b)

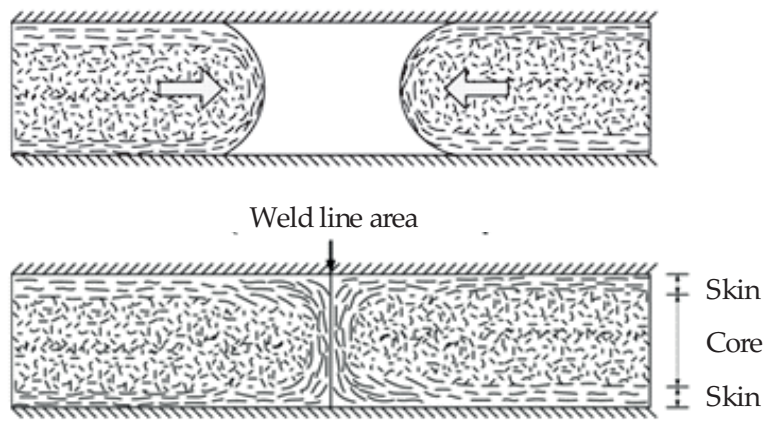

Fig. 8. Orientation of: a) polymer macromolecules [16], b) filler fibers (based on [21]) in the area of weld line in injection molded part

a)

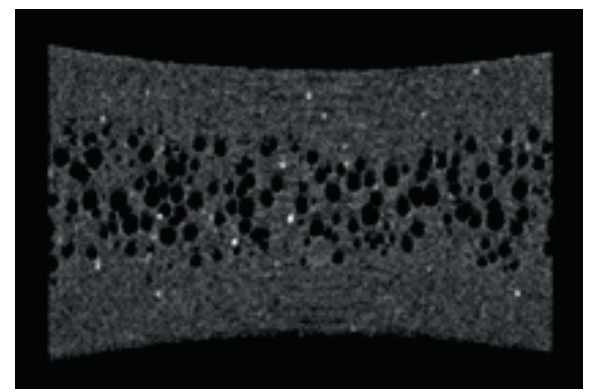

b)

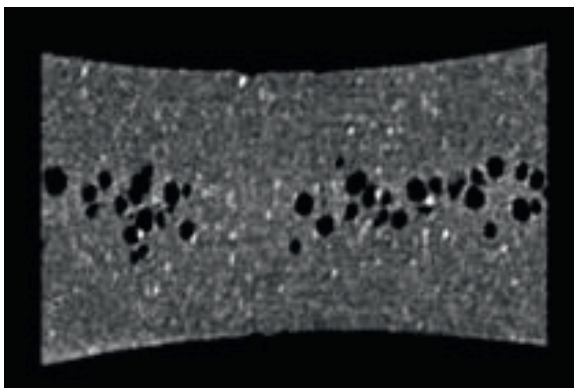

Fig. 9. Structure of the weld line zone in the longitudinal section of samples (small tensile bars) from the porous polypropylene: a) unfilled and filled with $20 \mathrm{wt} \%$ of talc, obtained by using the X-ray scanner; b) the images from the layer located in the middle of the sample thickness [20]

Another condition for obtaining correct moldings is the even thickness of their walls. The type of injected material and the value of its shrinkage are important. The maximum thickness difference for moldings made of amorphous and low shrinkage polymers is $25 \%$, while for semi crystalline polymers 15\% [16].

\section{PROPERTIES OF THE INJECTED MATERIAL}

The type of material processed largely influences the strength of the weld area. In the case of amorphous polymers, this strength is higher than that of semi crystalline ones [16]. Plastics characterized by a higher melt flow rate allow better packaging of the material in the cavity and, as a result, increase the strength of the parts. In polyethylene examinations [18] it was shown that the tensile strength of moldings with the weld area, made of polyethylene of the low melt flow index $(M F R=0.35 \mathrm{~g} / 10 \mathrm{~min})$, is about $16 \%$ lower with respect to the strength of moldings without this area. In the case of polyethylene characterized by a high melt flow rate $(M F R=21.30 \mathrm{~g} / 10 \mathrm{~min})$, these differences were small and only ranged from 3 to $5 \%$.

The worse properties of the molding in the weld area are the result of the orientation of the macromolecules on the fronts of the colliding streams (Fig. 8a). The addition of fillers, especially fibrous ones, to the plastic results in a deterioration of the strength properties due to the placement of filler particles parallel to the fronts of the material streams, as shown in Fig. 8b [19-21]. A similar effect is caused by the use of a pigment whose particles, of a length or width greater than the thickness or diameter, are oriented along the flow line of the material, which results not only in the strength properties but also in the colour of part in the weld area [5]. The higher the filler content and the longer the filler particles, the worse the strength properties of the parts in the weld area.

The chemical foaming agent added to the injected polymer can also influence the structure and mechanical strength of molded parts with weld lines [20]. It was found that the tensile strength of the porous samples from unfilled polypropylene decreased of about $17 \%$ in compare to solid ones. However, in the case of polypropylene filled with $20 \%$ talc, the tensile strength of solid and porous samples almost did not change. It can be explained by different foaming conditions in the weld line area in both cases. Examination of samples carried out by the X-ray scanner (Fig. 9) revealed the presence of numerous pores in the area of weld line zone in the case of porous moldings made of unfilled PP, which is the obvious reason for reducing their tensile strength. For samples formed from PP filled with talc, a smaller number of pores in the areas of weld lines or even no pores exactly in the stream connection line occur, due to the hindering of the foaming process by the filler particles gathered on the melt stream front.

\section{INJECTION CONDITIONS}

The quality of the bonding of colliding plastic streams can be improved, to a certain extent, by changing the injection conditions, mainly mold temperature, injection 
temperature or injection speed [2]. The liquid material filling the cavity, in contact with the much cooler walls, forms a layer of solidified material at the wall. The colliding plastic streams will only join in areas where the plastic will be sufficiently plasticized, therefore the thickness of the solid layer forming the skin of the part influences the width and depth of the V-notch formed in this area. In tests of polypropylene $+20 \%$ talcum moldings [6] and a polystyrene micro-parts [22], it was shown that the temperature of the mold had the greatest influence on the depth of the notch formed by the colliding streams of plasticized material. The increase in the injection speed and the temperature of the injected material has a beneficial effect on the condition of the surface in the region of the weld area. Increasing the mold temperature values and injection speed resulted in a 50\% lower V-notch depth and the width of the weld lines on the surface of the polystyrene moldings [22]. In Fig. 10 the influence of injection molding conditions: mold temperature, melt temperature and injection velocity on created V-notch in the weld area of parts made of PP filled with $20 \%$ of talcum has been shown. The lowest depth of the notch and the best quality of surface in the weld area was obtained when the injection parameters had higher values: mold temperature $80^{\circ} \mathrm{C}$, melt temperature $220^{\circ} \mathrm{C}$ and injection velocity $84.6 \mathrm{~mm} / \mathrm{s}$ [6]. Onken and Hopmann [23] in investigations of polycarbonate parts determined that the strength of weld lines depends mainly on melt temperature and holding pressure and stated that a higher melt temperature has a positive impact on weld line strength,

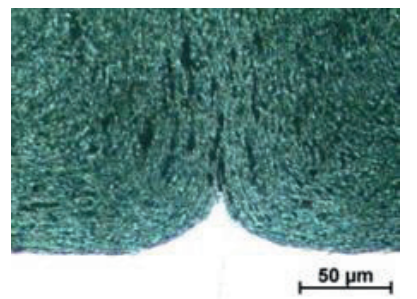

$$
\begin{aligned}
& T_{f}=20^{\circ} \mathrm{C} \\
& T_{w}=180^{\circ} \mathrm{C} \\
& v_{w}=28.2 \mathrm{~mm} / \mathrm{s}
\end{aligned}
$$

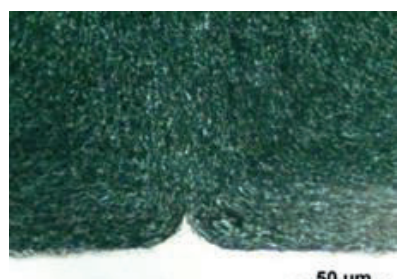

$$
\begin{aligned}
& T_{f}=80^{\circ} \mathrm{C} \\
& T_{w}=180^{\circ} \mathrm{C} \\
& v_{w}=28.2 \mathrm{~mm} / \mathrm{s}
\end{aligned}
$$

$\stackrel{50 \mu \mathrm{m}}{\longleftarrow}$

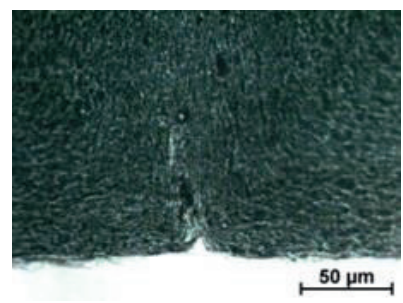

$$
\begin{aligned}
& T_{f}=80^{\circ} \mathrm{C} \\
& T_{w}=220^{\circ} \mathrm{C} \\
& v_{w}=84.6 \mathrm{~mm} / \mathrm{s}
\end{aligned}
$$

Fig. 10. The influence of injection molding parameters on the shape and the size of V-notch in the weld area of parts made of PP filled with $20 \mathrm{wt} \%$ of talc [6] while the strength declines with a higher holding pressure. Therefore, by appropriate selection of injection parameters, it is possible to influence both the strength and condition of the surface of the moldings in the area of weld lines.

\section{MOLD CONSTRUCTION}

Improper construction of the injection mold can also lead to the formation of weld areas. The main reasons for the occurrence of this defect include the incorrect design of mold venting and uncontrolled temperature variation in individual areas of the cavity. Sometimes, with a small cross-section of the gate and a high injection speed, jet injection may occur (Fig. 11) [18, 24]. The stream of melt moves rapidly until it collides with the wall of the cavity and then begins to curl. This promotes the unfavourable phenomenon of the formation of areas of joining plastic streams in a part. a)

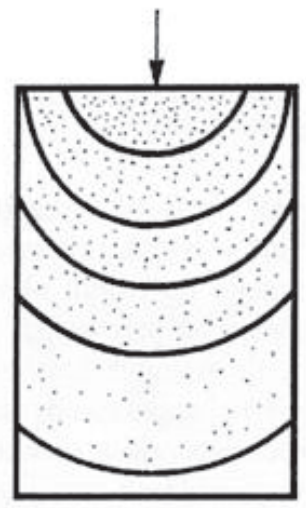

b)

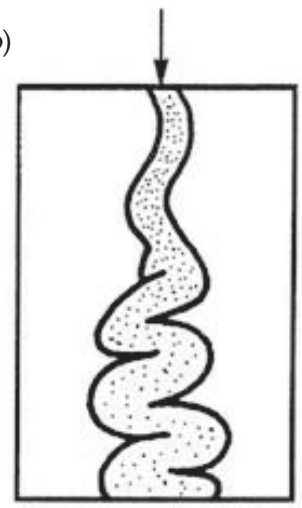

Fig. 11. The scheme of the injection mold cavity filling: a) regular, b) jetting [18]

a)
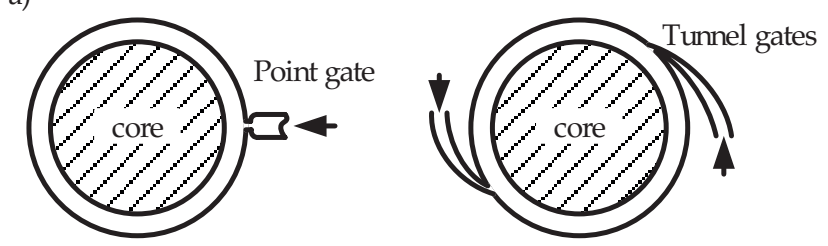

b)
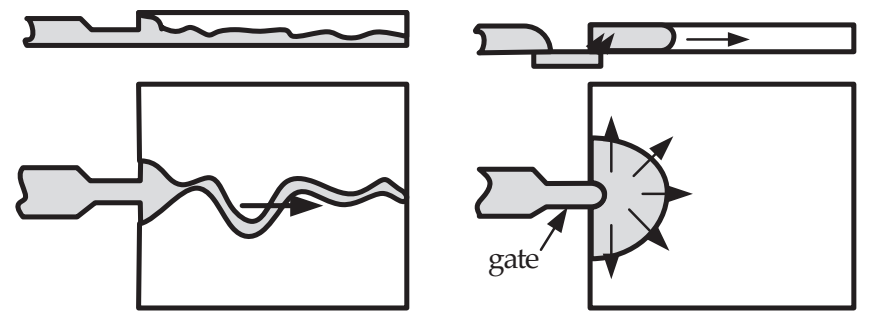

Fig. 12. Changing the construction of gates to eliminate the jetting during cavity filling: a) using a tunnel gate instead of a point one (based on [9]), b) moving the gate to a different plane than the runner and cavity (based on [23]) 
The change of the gate structure, e.g. from point to tunnel gate (Fig. 12a) [9] or the use of a gate located not in the channel and cavity axis (Fig. 12b) [24], allows to avoid jet filling of the cavity and the formation of the weld lines.

\section{INJECTION METHODS}

In the case of large moldings, and especially thinwalled ones, a multi-point feeding of the material to the cavity is necessary. In order to avoid weld areas, it is possible to use hot runner molds, with cascade filling of the cavity [5, 25-27]. In this process, the injection mold cavity with heated channels is filled by successively opening injection nozzles, arranged in the cavity in a manner forming one face of the flow front, which results in the lack of the weld area in the part (Fig. 13).

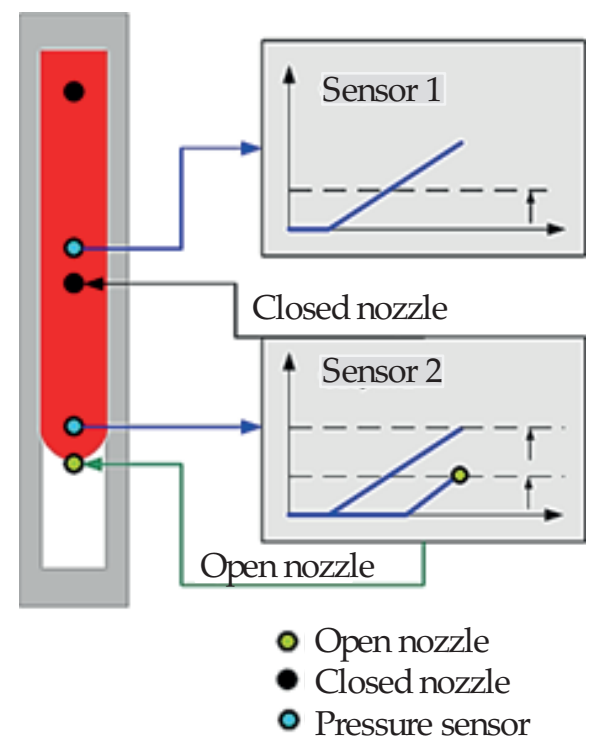

Fig. 13. Cascade filling of the injection mold cavity (based on [26])

Another injection molding method that allows the elimination of the weld areas is the pulsating injection process, in which a multiple, bidirectional flow of liquid material in the cavity is applied [20,25]. In this process, molded parts with highly oriented macromolecules are obtained, and in the case of composites also fibrous fillers, as a result of the oscillating motion of the liquid plastic stream in the cavity. There are two ways of pulsating injection: push-pull (Fig. 14) and multiple live-feed injec-

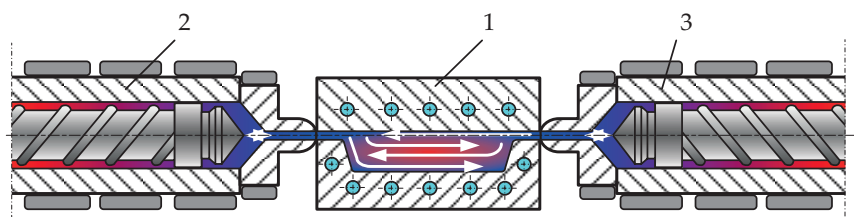

Fig. 14. The scheme of push-pull injection molding process: 1 injection mold, 2 - main plasticizing unit, 3 - additional plasticizing unit [25]

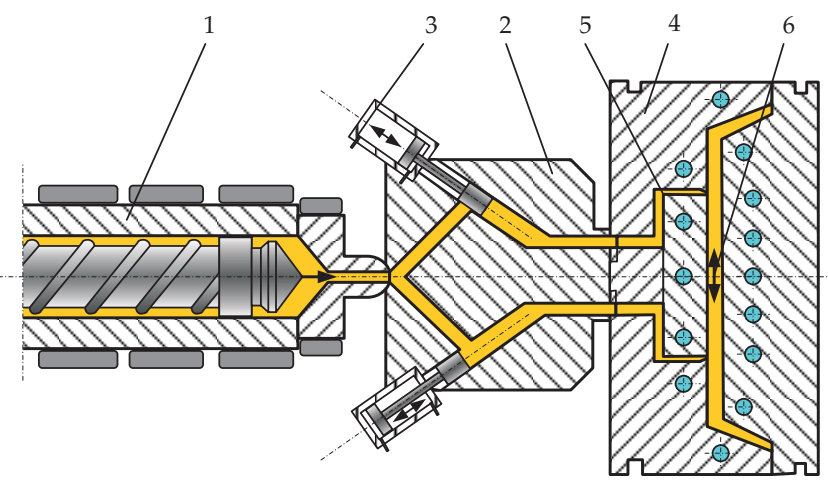

Fig. 15. Multiple live-feed injection molding process: 1 - plasticizing unit of the injection molding machine, 2 - distribution head, 3 - hydraulic systems, 4 - injection mold, 5 - runners, 6 area of weld line [25]

tion molding (Fig. 15). Multiple flow in two directions reduces the possibility of occurrence of weld areas due to distribution of material throughout the cavity, or, if such areas are formed, they are characterized by much greater strength than in the case of moldings produced in the conventional injection molding process.

The improvement of the strength of the weld area is possible due to the use of vibration injection molding $[9,25,28,29]$. In this process, plasticized material in the mold is subjected to vibrations at low frequency, which cause intense internal friction in the material, resulting in local generation of heat and a better combination of plastic streams. Figure 16 illustrates the vibration injection process. The mandrels move up and down using a hydraulically actuated cam. The mandrels installed in the mold travel on the road: the surface of the cavity and below this surface. After a certain number of displacements, the mandrels return to the initial position (to the surface of the cavity).

A solution to the problem of visible traces of the joining of plastic streams in molded parts there is a cyclic change in mold temperature (heating/cooling) during the injection cycle, e.g. induction heating in the areas where they occur and then cooling with water in the cooling channels system [28, 30-34]. In the injection phase at a higher temperature, the polymer macromolecules are easier to

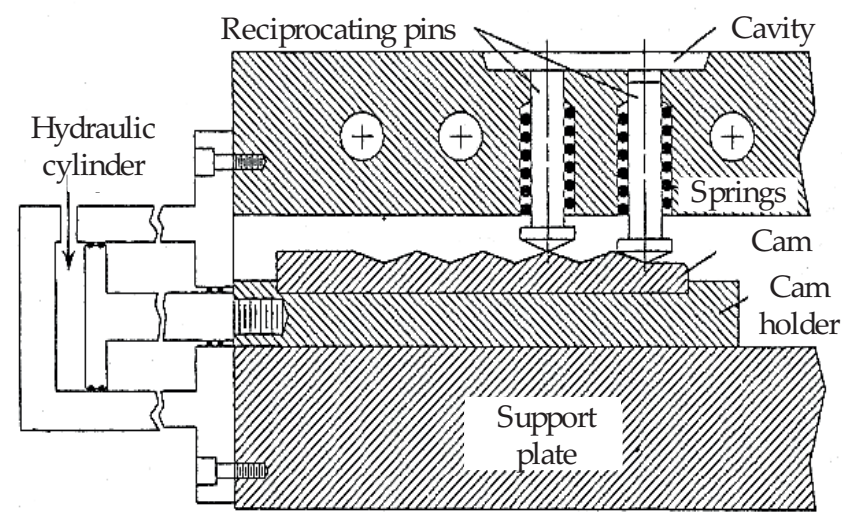

Fig. 16. Vibration injection molding (based on [9]) 
combine with each other, and as a result, a bonding with a higher strength and a part with a better surface condition is obtained. Figure 17 shows moldings of ABS copolymer obtained with various methods of heating and cooling of the injection mold. In the part produced without local induction heating, with a mold temperature of $50^{\circ} \mathrm{C}$, the weld line is clearly visible (Fig. 17a). While the use of the mold temperature variable in the area of plastic streams: induction heating of the mold to a temperature above the glass transition temperature of ABS (180$200^{\circ} \mathrm{C}$ ) during a few seconds before the injection of the material and then water cooling allowed to eliminate the weld lines (Fig. 17b).

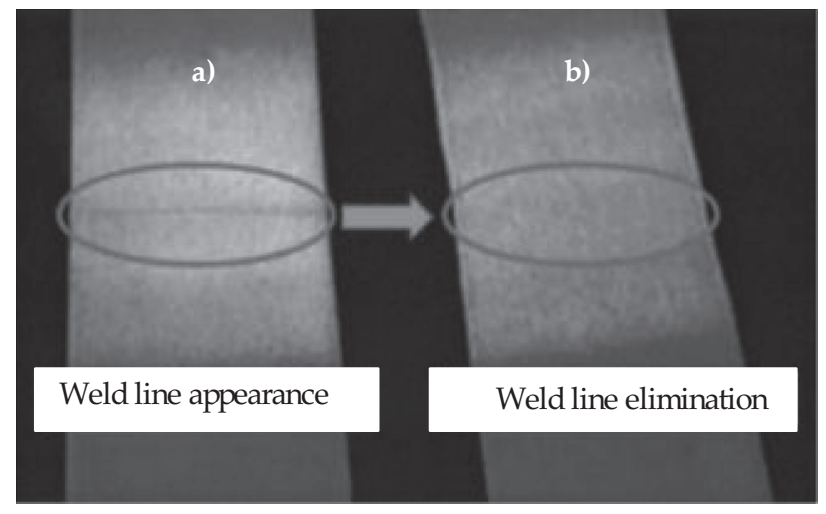

Fig. 17. Injection molded parts obtained: a) at a constant mold temperature of $50^{\circ} \mathrm{C}, \mathrm{b}$ ) during induction heating of the mold before the injection of the material [29]

\section{CONCLUSIONS}

The creation of weld areas in injection molded parts is a significant problem, especially in the case of manufacturing elements with a complex shape, with high demands as to their strength and surface condition, defined by uniform colour, gloss or smoothness. In this area, a visible weld line is created, which is a surface defect, and, moreover, an area with structure and properties another than the rest of the molding is formed. When filling the cavity the front of the plastic stream and its outer layers, as a result of contact with the cold form, have a lower temperature than the plastic core, which results in a significant temperature gradient in the plastic stream. The temperature gradient affects the cooling process of the material filling the mold cavity and causes thermal stresses arising in the moldings. At the end of the cooling process, compressive stresses arise in the outer layer of the material, while in the inside the tensile stresses occur. In addition, there are rheological and technological stresses, mainly related to the flow of the material and its meeting with the metal mold. These stresses also depend on the processing conditions. All this causes a complex state of internal stresses in a solidified part. Such a state, occurring at the place of collision of melt streams, can affect the worsening of part's properties in this area. As a result of collision of the liquid plastic streams, a specific orientation of the macromolecules arises, some of which are stretched in a direction perpendicular to the flow, and the others may bend and curl. The creation of a not ordered state of macromolecules in the weld area is another reason for the reduction of the properties of moldings. Thermal and mechanical degradation of the plastic in the considered area is also possible.

The most significant causes and ways to prevent the formation of these areas have been characterized. The first task when designing of injection molded parts with weld lines is to consider their placement in an unloaded area during use or invisible to the user. This can be achieved mainly by changing the place of feeding the material to the forming cavity. Computer simulations of cavity filling are helpful here. A better connection of colliding melt streams can be achieved by choosing the injection parameters, mainly by increasing the temperature and injection speed. However, it is an effective method only in the injection process of unfilled materials. In the case of polymers with fillers, especially fibrous ones, it is not sufficient, for example, to increase the temperature of the material, but it is then necessary to mechanically reorient the filler particles on the fronts of colliding streams. Unconventional injection molding methods are then effective, e.g. cascade, pulsed or vibration injection. Last research shows promising results obtained when variable temperature of injection mold is applied. Therefore, further examinations in the field of methods of mold temperature change during one injection cycle: fast heating in a phase of cavity filling (to high temperature, but in a short period of time to avoid polymer degradation) and then cooling appropriate to the requirements regarding the structure and properties of the moldings.

\section{REFERENCES}

[1] Kovács J.G., Sikló B.: Polymer Testing 2010, $29,910$. http://dx.doi.org/10.1016/j.polymertesting.2010.06.003

[2] Erhard G.: "Designing with Plastics", Hanser Gardner Publications, Munich 2006.

[3] Gordon Jr. M.J.: “Total Quality Process Control for Injection Molding", John Wiley \& Sons, Inc., New Jersey 2010.

[4] Miron M.C., Major Z., Adachi T.: "Fracture Behavior of Weld Lines in Injection Molded Components Loaded under Real Operating Conditions", $20^{\text {th }}$ European Conference on Fracture (ECF20), Procedia Materials Science 2014, 3, 2048.

http://dx.doi.org/10.1016/j.mspro.2014.06.330

[5] Beaumont J.P., Nagel R., Sherman R.: "Successful Injection Molding, Process, Design, and Simulation", Hanser Publishers, Munich 2002.

[6] Bociąga E., Szymański D.: Przetwórstwo Tworzyw 2013, 3, 150.

[7] Son Y., Ahn K.H., Char K.: Polymer Engineering and Science 2001, 41, 554. 
http://dx.doi.org/10.1002/pen.10752

[8] Geyera A., Bonten C.: "Enhancing the Weld Line Strength of Injection Molded Components", AIP Conference Proceedings 2055, 070023, 2019. https://doi.org/10.1063/1.5084867

[9] Malloy R.A.: "Plastic Part Design for Injection Molding", Carl Hanser Verlag, Munich 2011.

[10] Bociąga E., Jaruga T.: Polimery 2009, 54, 654. http://dx.doi.org/10.14314/polimery.2009.654

[11] Bociąga E., Jaruga T.: Archives of Materials Science and Engineering 2007, 28, 165.

[12] Injection Molding Defect: Molding Weld and Meld Line.

http://www.viewmold.com/sources/injection_molding_defects/Molding_weld_and_meld_line.html (accessedSept. 28, 2019).

[13] „Wady wyprasek. Środki zaradcze cz. 2.", TS Raport 2015, 75, 2.

[14] BTI and Moldex3D Provide The Most Advanced Solutions For Runner Design.

http://www.moldex3d.com/en/blog/customer_success/bti-2/ (accessed Sept. 28, 2019).

[15] Weld LinesiIn Injection Molded Parts. https://www.plastopialtd.com/weld-lines/ (accessed May 14, 2018).

[16] Bozzelli J.: "What to Do about Weak Weld Lines". https://www.ptonline.com/articles/what-to-doabout-weak-weld-lines (accessed Sept. 28, 2019).

[17] Weld Line Occurrence in Plastic Injection Molded Parts.

https://www.steinwall.com/wp-content/uploads/2016/05/Weld-Lines.pdf (accessed Sept. 28, 2019).

[18] Bociąga E.: „Procesy determinujące przepływ tworzywa w formie wtryskowej i jego efektywność", Politechnika Częstochowska, Częstochowa 2001, pp. 28, 67, 105.

[19] Coping with Weak Weld Lines. https://www.ptonline.com/columns/coping-withweak-weld-lines (accessed Sept. 28, 2019).

[20] Bociąga E., Kaptacz S., Duda P., Rudawska A.: Polymer Engineering and Science 2019, 59, 1710. http://dx.doi.org/10.1002/PEN.25170
[21] Osswald T.A., Turng L.S., Gramann P.J.: “Injection Molding Handbook", Hanser Publishers, Munich 2001.

[22] Tosello G., Gava A., Hansen H.N. et al.: Wear 2009, 266,534 .

http://dx.doi.org/10.1016/j.wear.2008.04.077

[23] Onken J., Hopmann C.: International Polymer Science and Technology 2016, 43, T-1.

[24] How to Avoid Jetting when Injection Molding. http://www.anole-hot-runner.com/how-to-avoid-jetting-when-injection-molding_484.htm (accessed Sept. 28, 2019).

[25] Bociąga E.: „Specjalne metody wtryskiwania tworzyw polimerowych", Wydawnictwo Naukowo-Techniczne, Warszawa 2008, p. 139.

[26] Berz S., Carvani M.: Kunststoffe International 2016, 01-02, 36.

[27] Bociąga E.: „Nowoczesne materiały polimerowe i ich przetwórstwo. Część 1" (Ed. Klepka T.), Politechnika Lubelska, Lublin 2014, p. 89.

[28] Nasir S.M., Ismail K.A., Shayfull Z., Shuaib N.A.: International Review of Mechanical Engineering 2013, 7, 977.

[29] Yan Z., Shen K.Z., Zhang J.: Journal of Applied Polymer Science 2004, 91, 1514. http://dx.doi.org/10.1002/app.13333

[30] Chen S.Ch., Jong W.R., Chang J.A.: Journal of Applied Polymer Science 2006, 101, 1174. http://dx.doi.org/10.1002/app.24070

[31] Park K., Sohn D-H., Cho K-H.: Journal of Mechanical Science and Technology 2010, 24, 149. http://dx.doi.org/10.1007/s12206-009-1127-4

[32] Zawilski R., Szostak M.: Przetwórstwo Tworzyw 2013, 3, 292.

[33] Mrozek K., Chen S.Ch.: Journal of Applied Polymer Science 2017, 134, 44992. http://dx.doi.org/10.1002/app.44992

[34] Mrozek K.: International Journal of Simulation Modelling 2018, 17, 220. http://dx.doi.org/10.2507/IJSIMM17(2)415

Received 3 X 2019 